\title{
Evidence of predation on the Helmeted water toad Calyptocephalella gayi (Duméril \& Bibron, 1841) by the invasive African clawed frog Xenopus laevis (Daudin 1802)
}

\section{Evidencia de depredación sobre la rana chilena Calyptocephalella gayi (Duméril \& Bibron, 1841) por la rana africana invasora Xenopus laevis (Daudin 1802)}

\section{Pablo Fibla ${ }^{1, *}$, José M. Serrano ${ }^{1,2}$, Franco Cruz-Jofré ${ }^{1,3}$, Alejandra A. Fabres ${ }^{1}$, Francisco Ramírez ${ }^{4}$, Paola A. Sáez ${ }^{1}$, Katherin E. Otálora ${ }^{1}$ \& Marco A. Méndez ${ }^{1}$}

${ }^{1}$ Laboratorio de Genética y Evolución, Departamento de Ciencias Ecológicas, Facultad de Ciencias, Universidad de Chile, Santiago, Chile.

²Laboratorio de Comunicación Animal, Vicerrectoría de Investigación y Postgrado, Universidad Católica del Maule, Talca, Chile.

${ }^{3}$ Facultad de Recursos Naturales y Medicina Veterinaria, Universidad Santo Tomás, Viña del Mar, Chile.

${ }^{4}$ Instituto de Geografía, Pontificia Universidad Católica de Chile, Santiago, Chile.

*E-mail: pfibla@gmail.com

\begin{abstract}
We report the first record of predation on a Helmeted water toad Calyptocephalella gayi tadpole by an adult specimen of the invasive African clawed frog Xenopus laevis in the locality of Pichi, Alhué (Santiago Metropolitan Region). This finding is discussed in the light of new sightings, in which both species have been detected to coexist in different localities of central Chile.

Keywords: Anura, Central Chile, invasive species, semi-urban wetlands

RESUMEN

Se reporta el primer registro de depredación de una larva de rana chilena Calyptocephalella gayi por un espécimen adulto de la rana africana invasora Xenopus laevis en la localidad de Pichi, Alhué (Región Metropolitana de Santiago). Este hallazgo es discutido a la luz de nuevos avistamientos en los cuales ambas especies han sido detectadas coexistiendo en diferentes localidades de Chile central.
\end{abstract}

Palabras clave: Anura, Chile central, especie invasora, humedales semiurbanos

Invasive alien species disrupt ecological processes and functions, mainly predating on native species or competing, to the point of exclusion, with them. This creates a severe damage to local biodiversity and ecosystems (Mooney 2005). One worldwide spread invasive amphibian is the African clawed frog Xenopus laevis (Daudin 1802). This species is native to sub-Saharan Africa, known for being totally aquatic, but with possible overland movement during drought or heavy rainfall (Measey 2016). X. laevis has been considered as an ecologically competitive alien species, due to its rapacious unspecialized carnivorous habits on aquatic and terrestrial species (e.g. Lillo et al. 2011; Amaral \& Rebelo 2012). On the other hand, it has been related to the cause of the global decline of amphibians, as being the main vector of emerging diseases such as chytridiomycosis and Ranavirus (Solís et al. 2010; Soto-Azat et al. 2016; O'Hanlon et al. 2018). The invasive routes of $X$. laevis in all continents, except Oceania, are strongly related to human spread, given its popularization as a pet (Measey et al. 2012), and its use in laboratory for pregnancy test during the last 
century and developmental biology (Soto-Azat et al. 2013). Special conservation concerns arise from $X$. laevis adaptability to Mediterranean environments with similar conditions than its native distribution (Lillo et al. 2011; Ihlow et al. 2016). Predictive models based on habitat suitability suggest that an invasion towards north and southern Chile is feasible despite the low genetic diversity showed (Lobos et al. 2013, 2014).

Numerous studies from around the world have examined the local diet of $X$. laevis, suggesting that frogs in general, are consumed at a low proportion by this alien species (Courant et al. 2017). However, evidence suggests that the effect of $X$. laevis would be different, on the reproduction of native amphibian populations (Lillo et al. 2011).

In Chile, X. laevis was first reported in the 1970's and has currently established naturalized populations between Atacama and Maule Regions, where the core of its distribution is in central Chile (Jaksic 1998; Lobos \& Jaksic 2005; Mora et al. 2019). Central Chile is considered a biodiversity hotspot (Myers et al. 2000); thus, it is very important to establish the ecological interactions between the alien species, $X$. laevis, and native fauna as well as its effects. In 1998, Jaksic et al. noted that "No information exists on the possible effects of the introduction of the African clawed frog on sympatric native fauna in central Chile". Reports since the invasion of $X$. laevis in central Chile suggest a rapid declination of other native amphibians. Three years after the first record of $X$. laevis in Talagante (Mapocho river, 1988), an event called "the silent spring" occurred, where mating calls from the local amphibian Pleurodema thaul (Schneider, 1799) disappeared. This event has been associated to the introduction of $X$. laevis into the water system (Rottman 2012); however, there is no direct evidence of predation of native amphibians by this invasive species, or any other detrimental interaction on local fauna caused by X. laevis (Lobos et al. 1999; Lobos \& Measey 2002). Recently, Mora et al. (2016) reported predation of the Helmeted water toad (Chilean toad) Callyptocephalella gayi (Duméril and Bibron, 1841) on adult specimens of $X$. laevis and they suggested that this interaction could result in an easy infection with chytrid fungus by direct contact. A plausible scenario is that $X$. laevis could represent a predator of native amphibian larvae and freshwater fishes from Chile, because of its carnivorous diet and size. Up to now, evidence suggests that the (natural) diet of $X$. laevis in Chile is made up of chiefly zoobenthic and zooplanktonic taxa, mostly Chironomids, Ostracods and small invertebrates, mostly snails of the genus Physa (Lobos \& Jaksic 2005), but no vertebrates.

In the context of the project "Desarrollo de investigación aplicada y actividades de difusión para la conservación de la rana chilena (Calyptocephalella gayi) en la Región Metropolitana de Santiago" of the Chilean Ministry of the Environment, fieldwork campaigns were done throughout the year to monitor populations of $C$. gayi in the Metropolitan Region (MR). The objectives of these campaigns were to determine the presence of $C$. gayi populations and sympatric species, to obtain data on emerging diseases and genetic samples, and to measure the water quality where they live. During one of the monitoring fieldworks of the Helmeted water toad population on June 11th of 2018, in the Pichi stream at the Cajón de Lisboa (-33.971457, -71.059351), Alhué, a total of ten C. gayi larvae (no adults) and an adult specimen of $X$. laevis ( $S V L=52 \mathrm{~mm}$ ) were collected. Specimens of each species were put in different cages, and before obtaining the genetic samples, the specimen of $X$. laevis regurgitated a partially digested $C$. gayi tadpole (Figure 1 ). It is possible to differentiate $C$. gayi larvae from other species present at this site (i.e. P. thaul and X. laevis) by its large size, stout caudal musculature, the presence of dark spots in the dorsum and tail, and the absence of cloacal tube (Díaz \& Valencia 1985). After taking genetic samples from the collected specimens of $C$. gayi, the $X$. laevis specimen was euthanized by immersion in a benzocaine solution, while $C$. gayi larvae were returned to its habitat (except for the digested tadpole). Both specimens, partially digested tadpole of $C$. gayi and adult $X$. laevis, were fixed in $100 \%$ Ethanol and deposited in the herpetological collection of the Departamento de Biología Celular y Genética de la Universidad de Chile (DBGUCH-1806011 and DBGUCH-1806012 respectively). This observation confirms the predation of the Helmeted water toad's larvae by the African clawed frog in central Chile. Since Chilean populations of $X$. laevis can reach a large size (Lobos \& Measey 2002), the aquatic vertebrate predator habit of this species implies an imminent danger to all other native aquatic vertebrates (i.e. fishes and amphibians). Calyptocephalella gayi is endemic to Chile and is currently classified as Vulnerable (A2ad criteria) by the International Union for Conservation of Nature (IUCN) and by the Reglamento de Clasificacion de Especies (RCE) of Chile (DS 50 MINSEGPRES, 2008). Populations of this species are currently declining in central Chile, being practically absent in ponds and lagoons near towns, where it once was very abundant (IUCN 2010). Even though predation on C. gayi by invasive species has not been considered before among the principal threats, we found five sites in the MR in which $X$. laevis coexist with $C$. gayi (Table 1). Most of these sites have conditions that are favorable for the invasive species, like lentic and turbid water (Lobos et al. 2013). Therefore, the next efforts should be put into carrying out continuous monitoring fieldwork on sites where these two species coexist, mainly to quantify the effects of predation that the African clawed frog has on the Helmeted water toad's population sizes, if there is any significative effect at all. 


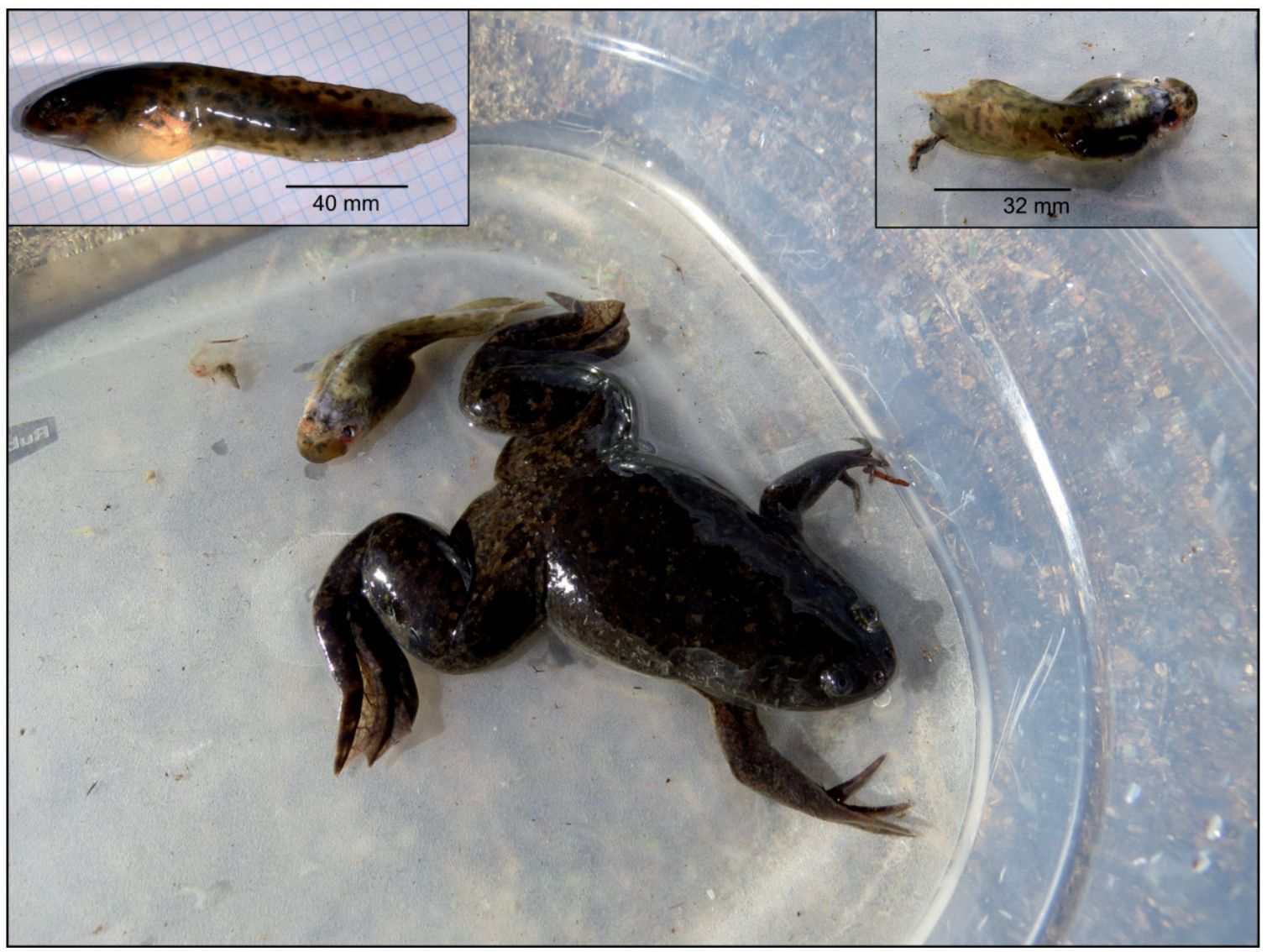

Figure 1. Xenopus laevis adult next to the regurgitated Calyptocephalella gayi tadpole. Upper panels show a zoom of the regurgitated tadpole (right) and a live tadpole captured in the study site (left). / Adulto de Xenopus laevis al lado la larva rejurgitada de Calyptocephalella gayi (Duméril and Bibron, 1841). Los paneles superiores muestran un acercamiento de la larva regurgitada (derecha) y de una larva viva (izquierda) capturadas en el sitio de estudio.

TABLE 1. New records of Calyptocephalella gayi, Xenopus laevis and other native amphibians distributed in the Metropolitan region, Chile Central. P. thaul = Pleurodema thaul; $R$. arunco = Rhinella arunco (Molina, 1782). / Nuevos registros de Calyptocephalella gayi, Xenopus laevis y otros anfibios nativos distribuidos en la región Metropolitana, Chile central. $P$. thaul = Pleurodema thaul; $R$. arunco = Rhinella arunco (Molina, 1782).

\begin{tabular}{lcccc}
\hline Locality & \multicolumn{2}{c}{ Georreference (UTM) } & Native amphibians & $\begin{array}{c}\text { Presence of } \\
\text { X. laevis }\end{array}$ \\
\hline El Pangal, Curacaví & 300176 & 6303890 & C. gayi, P. thaul, R. arunco & Present \\
Estero Paine, Hospital & 324013 & 6281001 & C. gayi, P. thaul & Present \\
El Trapiche, Peñaflor & 324028 & 6281030 & C. gayi, P. thaul & Present \\
Rungue, Tiltil & 319747 & 6342022 & C. gayi, R. arunco & Present \\
Picipozas, El Paico & 311490 & 6267953 & C. gayi, P. thaul & Absent \\
Mapocho river, El Monte & 316892 & 6271001 & C. gayi & Absent \\
Pichi, Alhué & 309420 & 6238689 & C. gayi, P. thaul & Present \\
\hline
\end{tabular}




\section{ACKNOWLEDGEMENTS}

Project "Desarrollo de investigación aplicada y actividades de difusión para la conservación de la Rana chilena (Calyptocephalella gayi) en la Región Metropolitana de Santiago", Seremi del Medio Ambiente, Region Metropolitana; Fondo de apoyo académico DCE PEEI. We want to thank to Carolina Gallardo, Luis Pastenes and Álvaro Zúñiga, who collaborated in the earlier phases of this Project. This research was conducted in accordance with Chilean law under permit no. 399/2018 of the Servicio Agrícola y Ganadero de Chile.

\section{REFERENCES}

Amaral, P., Rebelo, R. 2012. Diet of invasive clawed frog Xenopus laevis at Lage stream (Oeiras, W Portugal). Herpetological Journal 22(3): 187-190.

Courant, J., Vogt, S., Marques, R. 2017. Are invasive populations characterized by a broader diet than native populations? PeerJ 5: e3250.

Díaz, N.F., Valencia, J. 1985. Larval Morphology and Phenetic Relationships of the Chilean Alsodes, Telmatobius, Caudiverbera and Insuetophrynus (Anura: Leptodactylidae). Copeia 1: 175-181.

Ihlow, F., Courant, J., Secondi, J., Herrel, A., Rebelo, R., Measey, G.J., Lillo, F. De Villiers F.A., Vogt, S., De Busschere, C., Backeljau, T., Rödder, D. 2016. Impacts of Climate Change on the Global Invasion Potential of the African Clawed Frog Xenopus laevis. PLoS ONE 11(6): e0154869.

Jaksic, F.M. 1998. Vertebrate invaders and their ecological impacts in Chile. Biodiversity and Conservation 7(11): 1427-1445.

Lillo, F., Faraone, F.P., Valvo, M.L. 2011. Can the introduction of Xenopus laevis affect native amphibian populations? Reduction of reproductive occurrence in presence of the invasive species. Biological Invasions 13(7): 1533-1541.

Lobos, G., Jaksic, F.M. 2005. The ongoing invasion of African clawed frogs (Xenopus laevis) in Chile: causes of concern. Biodiversity and Conservation 14(2): 429-439.

Lobos, G., Measey, G.J. 2002. Invasive populations of Xenopus laevis (Daudin) in Chile. Herpetological Journal 12(4): 163-168.

Lobos, G., Cattan, P., Estades, C., Jaksic, F.M. 2013. Invasive African clawed frog Xenopus laevis in southern South America: key factors and predictions. Studies on Neotropical Fauna and Environment 48(1): 1-12.

Lobos, G., Méndez, M.A., Cattan, P., Jaksic, F.M. 2014. Low genetic diversity of the successful invasive African clawed frog Xenopus laevis (Pipidae) in Chile. Studies on Neotropical Fauna and Environment: 49(1): 50-60.

Measey, G.J. 2016. Overland movement in African clawed frogs (Xenopus laevis): a systematic review. PeerJ 4: e2474.

Measey, G.J., Rödder, D., Green, S.L., Kobayashi, R., Lillo, F., Lobos, G., Rebelo, R., Thirion, J.M. 2012 Ongoing invasions of the African clawed frog, Xenopus laevis: a global review. Biological Invasions: 14(11): 2255-2270.

Mooney, H.A. 2005. Invasive alien species: a new synthesis. International Council for Science; Washington, Scientific Committee on Problems of the Environment, Island press. $273 \mathrm{pp}$.

Mora, M.C., Constanzo-Chávez, J., Contardo, J.E., Labra, A. 2016. First report of predation by Calyptocephalella gayi upon the invasive species Xenopus laevis (Amphibia, Anura, Calyptocephalellidae and Pipidae). Herpetology Notes 9: 171-173.

Mora, M., Pons, D.J., Peñafie-Ricaurte, A., Alvarado-Rybak, M., Lebuy, S., Soto-Azat, C. 2019. High abundance of invasive African clawed frog Xenopus laevis in Chile: challenges for their control and updated invasive distribution. Management of Biological Invasions 10(2): 377-388.

Myers, N., Mittermeier, R.A., Mittermeier, C.G., da Fonseca, G.A., Kentt, J. 2000. Biodiversity hotspots for conservation priorities. Nature 403 (6772): 853-858.

O'Hanlon, S.J., Rieux, A., Farrer, R.A., Rosa, G.M., Waldman, B., Bataille, A., Kosch, T.A., Murray, K.A., Brankovics, B., Fumagalli, M., Martin, M.D., Wales, N., Alvarado-Rybak, M., Bates, K.A., Berger, L., Böll, S., Brookes, L., Clare, F., Courtois, E.A., Cunningham, A.A., et al. 2018. Recent Asian origin of chytrid fungi causing global amphibian declines. Science 360(6389): 621-627.

Rottmann, J. 2012. Antecedentes sobre la importancia de los anfibios chilenos - Santiago. In: Soto-Azat, C., ValenzuelaSánchez, A. (Eds) Conservación de anfibios de Chile: 1012. Universidad Nacional Andrés Bello, Santiago.

Solís, R., Lobos, G., Walker, S.F., Fisher, M., Bosch, J. 2010. Presence of Batrachochytrium dendrobatidis in feral populations of Xenopus laevis in Chile. Biological Invasions 12(6): 1641-1646.

Soto-Azat, C., Valenzuela-Sánchez, A., Collen, B., Rowcliffe, J.M., Veloso, A., Cunningham, A.A. 2013. The population decline and extinction of Darwin's frogs. PLoS ONE 8(6): e66957.

Soto-Azat, C., Peñafiel-Ricaurte, A., Price, S.J., SallaberryPincheira, N., García, M.P., Alvarado-Rybak, M., Cunningham, A.A. 2016. Xenopus laevis and emerging amphibian pathogens in Chile. EcoHealth 13(4): 775-783.

Received: 18.07.2019

Accepted: 03.01.2020 